\title{
Movements, winter distribution and activity patterns of Falkland and brown skuas: insights from loggers and isotopes
}

\author{
R. A. Phillips ${ }^{1, *}$, P. Catry ${ }^{2}$, J. R. D. Silk ${ }^{1}$, S. Bearhop ${ }^{3,6}$, R. McGill ${ }^{4}$, V. Afanasyev ${ }^{1}$, I. J. Strange \\ ${ }^{1}$ British Antarctic Survey, Natural Environment Research Council, High Cross, Madingley Road, Cambridge CB3 0ET, UK \\ ${ }^{2}$ Unidade de Investigação em Eco-Etologia, Instituto Superior de Psicologia Aplicada, Rua Jardim do Tabaco 44, $1149-041$ \\ Lisboa, Portugal \\ ${ }^{3}$ Quercus School of Biology \& Biochemistry, MBC, Queen's University of Belfast, Lisburn Road, Belfast BT9 7BL, UK \\ ${ }^{4}$ Scottish Universities Environmental Research Centre, Scottish Enterprise Technology Park, East Kilbride G75 0QF, UK \\ ${ }^{5}$ New Island Conservation Trust, The Dolphins, Stanley, Falkland Islands \\ ${ }^{6}$ Present address: Centre for Ecology \& Conservation, School of Biosciences, University of Exeter, Cornwall Campus, \\ Tremough, Penryn, Cornwall TR10 9EZ, UK
}

\begin{abstract}
In the first published study of the wintering ranges and activity patterns of skuas from any colony, we combined tracking (geolocator) and stable isotope analysis in a comparison of migration behaviour of brown skuas Catharacta lonnbergi and Falkland skuas C. antarctica from South Georgia and the Falkland Islands, respectively. Brown skuas, particularly failed breeders, departed and returned to the colony much earlier than Falkland skuas, and 2 of 3 brown skuas performed a pre-laying exodus. During winter, brown skuas were distributed widely over deep, oceanic water within the Argentine Basin $\left(37\right.$ to $\left.52^{\circ} \mathrm{S}\right)$ between the Antarctic Polar Front and the northern sub-tropical Front. Falkland skuas, by comparison, wintered mainly in subantarctic waters around the central Patagonian shelf-break (40 to $52^{\circ} \mathrm{S}$ ). Much greater overlap existed among core areas within than between species, and sex did not influence distribution. The partial inter-specific spatial segregation was also reflected in a divergence in activity patterns, with brown skuas in flight for a greater proportion, and more time on average, during both daylight and darkness. Both species of skua spent far more time on the water than do foraging albatrosses, and there was limited overlap between their nonbreeding distributions and those of large procellariids from the same archipelagos. Stable isotope signatures of brown skua feathers indicated that distributions of tracked birds were typical of most or all of the breeding population, and were consistent from year to year. None was characteristic of species that winter on adjacent continental shelves or off south-west Europe. Isotope values also suggested a mixed diet for brown skuas of zooplankton, low trophic-level squid and fish, with little or no reliance on seabird predation or fisheries.
\end{abstract}

KEY WORDS: Foraging behaviour $\cdot$ Habitat preferences $\cdot$ Niche specialisation $\cdot$ Migration $\cdot$ Spatial segregation · Site fidelity

Resale or republication not permitted without written consent of the publisher

\section{INTRODUCTION}

Although many seabirds are highly migratory, dispersing hundreds or thousands of km from the colony when not under the central-place foraging constraint associated with land-based reproduction, this aspect of their lifestyle remains relatively little known. The traditional approach to identification of nonbreeding (in most cases, wintering) ranges has been the analysis of ringing recoveries, which often suffers from important biases because of variability in reporting rates (Wernham et al. 2002). Only in the last decade or so have 
researchers begun to use other techniques, including geolocators and environmental tracers such as stable isotopes, to examine individual migration strategies in any detail (Cherel et al. 2000, 2006, Grémillet et al. 2000, Croxall et al. 2005, Phillips et al. 2005b).

During the breeding season, adults are amenable to the short-term deployment and retrieval of devices such as satellite transmitters and Global Positioning System (GPS) loggers, and the burgeoning of studies since the early 1990s has provided unprecedented opportunities to investigate the complex variation within and between species in at-sea distributions (Hyrenbach et al. 2002, Waugh \& Weimerskirch 2003, Phillips et al. 2005a). These suggest a number of mechanisms that may reduce the level of inter-specific competition for resources, including spatial, dietary and behavioural segregation at sea, and to a lesser extent differences in timing of breeding and hence peak demand for prey. The limited number of studies of conspecifics breeding at various levels of geographical proximity usually indicates little overlap in feeding areas even if colonies are relatively close, although this varies with breeding stage (Brothers et al. 1998, Huin 2002). Similarly, the few analyses of inter- and intraspecific competition among non-breeding seabirds suggest a moderate to high degree of spatio-temporal isolation between congeners and conspecifics (Croxall et al. 2005, Phillips et al. 2005b), although with one recent exception (Shaffer et al. 2006). However, these have all been in procellariids, with much less tracking effort directed at other taxonomic groups.

Skuas (family Sterorcorariidae; taxonomy follows BirdLife International) are a group of highly opportunistic predator-scavengers (Furness 1987, Phillips et al. 1997, 2004a). During the breeding season, some species or populations catch few or no prey by themselves at sea, which is perhaps why skuas are sometimes excluded from comparative analyses of seabird ecology and life history (e.g. Fairbairn \& Shine 1993, Serrano-Meneses \& Székely 2006). Yet they may be highly pelagic at other times of year. To date, their wintering ranges have been inferred primarily from at-sea sightings and (mainly coastal) ringing recoveries, which indicate that the small Stercorarius spp., and large numbers of juvenile, but not necessarily adult, south polar skua Catharacta maccormicki regularly perform trans-equatorial migrations (Furness 1987, Marchant \& Higgins 1990). However, based on at-sea observations, other southern hemisphere Catharacta in addition to south polar skua must also spend part or all of the winter far from coasts (Marchant \& Higgins 1990). Indeed, a recent genetic and morphological analysis suggested that 2 birds captured in the UK were probably Falkland skua $C$. antarctica (Votier et al. 2004), although a forthcoming corrigendum now indicates that it is only possible to conclude that the birds were southern hemisphere Catharacta. Therefore, the lack of tracking data and the inability to discriminate age, provenance and even species within this morphologically similar genus still precludes detailed analysis of the predominance either of longdistance migration or the extent of oceanic (deep water) foraging within most members of the group.

This study combined tracking (geolocator) and stable isotope analysis in an intra- and inter-specific comparison of wintering range and activity patterns of brown skuas Catharacta lonnbergi and Falkland skuas C. antarctica breeding at South Georgia and the Falkland Islands, respectively ( $1500 \mathrm{~km}$ apart). Stable isotope ratios in animal tissues reflect those of their prey during tissue formation: the ${ }^{15} \mathrm{~N}$ to ${ }^{14} \mathrm{~N}$ ratio (expressed as $\delta^{15} \mathrm{~N}$ ) increases in a stepwise manner by $\sim 3$ to $5 \%$ at each trophic level; the ${ }^{13} \mathrm{C}$ to ${ }^{12} \mathrm{C}$ ratio (expressed as $\delta^{13} \mathrm{C}$ ) increases to a lesser extent with trophic level (by $\sim 0.5$ to $1 \%$ ) but provides spatial information reflecting latitudinal distribution and the relative reliance on an inshore vs. offshore and benthic vs. pelagic diet (Michener \& Schell 1994, Bearhop et al. 2000, Cherel et al. 2006). Stable isotope levels in body feathers are fixed after formation and, since skuas moult after breeding, reflect diet more or less exclusively during the nonbreeding period. As relatively few individuals were tracked using loggers, feather isotope values were compared to those of a much larger sample of skuas and to 2 other species of generalist predator from South Georgia known to winter on South American and southern African continental shelves, to determine if the distribution of the tracked birds was likely to be representative of the population as a whole. Feather stable isotope signatures were also compared in consecutive years, from which it was possible to infer the level of dietary and wintering site fidelity.

\section{MATERIALS AND METHODS}

Logger deployment and processing. Fieldwork was carried out on brown skuas at Bird Island, South Georgia $\left(54^{\circ} 00^{\prime} \mathrm{S}, 38^{\circ} 03^{\prime} \mathrm{W}\right.$ ), in (austral) summers $2001 / 02$ and 2002/03, and on Falkland skuas at New Island, Falkland Islands $\left(51^{\circ} 43^{\prime} \mathrm{S}, 61^{\circ} 18^{\prime} \mathrm{W}\right)$, in summers 2003/04 and 2004/05. In total, there were 467 breeding pairs (132 pairs $\mathrm{km}^{-2}$ ) of brown skuas at Bird Island in 2003/04 (Phillips et al. 2004a), and 500 to 1000 pairs of Falkland skuas at New Island. Two types of logger were used in this study: (1) a Global Location Sensor (GLS) logger weighing $7 \mathrm{~g}$ that was deployed on 18 birds at Bird Island in December 2001 to January 2002, which did not collect immersion data and which was programmed to stop recording after $300 \mathrm{~d}$ to save bat- 
tery life for later download; and (2) a combined GLS and immersion logger weighing $9 \mathrm{~g}$ that was deployed on a further 10 birds at Bird Island in December 2001 to January 2002, and on 30 birds at New Island in December 2003. Self-amalgamating tape was wrapped around part of the logger to reduce slippage, and then loggers were attached by 1 or 2 cable-ties to a Darvic band fitted on the tarsus. All devices were deployed on breeding adults with eggs or young chicks ( $<7 \mathrm{~d}$ old), in some cases both members of the pair (Bird Island only). A random sample of 8 to 10 body feathers was collected from a total of 40 skuas at Bird Island in the first season. Maximum logger mass (9 g) corresponded to $\sim 0.5 \%$ of mean body mass at Bird Island (see 'Results'). Sex was determined at New Island from behavioural observations (courtship feeding), and at Bird Island by analysis of DNA extracted from a $100 \mu \mathrm{l}$ blood sample taken from the tarsal vein. At both sites, loggers were retrieved at the start of the following breeding season, and at Bird Island a second sample of body feathers was collected. Body mass during incubation, breeding success and hatching date of the first/only chick (for details see Phillips et al. 2004a) were compared, if available, between instrumented birds and controls to test for potential deleterious effects of the loggers.

Light data from the GLS loggers were processed using MultiTrace software (Jensen Software Systems), according to Phillips et al. (2004b). Sunset and sunrise times were estimated from thresholds in light curves, latitude derived from day length and longitude from the time of local midday with respect to Greenwich Mean Time and day of the year, providing 2 locations per day. During processing, locations derived from curves with apparent interruptions around sunset and sunrise, or that required unrealistic flight speeds (>35 $\mathrm{km} \mathrm{h}^{-1}$ sustained over a $48 \mathrm{~h}$ period) were identified and later excluded, if appropriate. Validated data were smoothed twice (Phillips et al. 2004b). Concurrent deployment of GLS loggers and satellitetransmitters in black-browed albatrosses Thalassarche melanophrys indicates a mean accuracy \pm SD of $186 \pm$ $114 \mathrm{~km}$, which is more than adequate for tracking wintering foraging ranges of pelagic species (Phillips et al. 2004 b). Locations were unavailable for variable periods ( 2 to $4 \mathrm{wk}$ ) around the equinoxes (23 September and 21 March) when it is difficult or impossible to estimate latitude.

Birds were considered to be wintering from the onset of the outward migration in February to April, to their return the following September to November. Timing of departure and return was identified from location and activity (immersion) records, as skuas at sea always spent a substantial proportion of the night on the water. Key wintering areas were identified by gen- erating kernel density maps in a Lambert Equal-Area Azimuthal (South Pole) projection using the ESRI ${ }^{\circledR}$ ArcGIS $^{\mathrm{TM}}$ Spatial Analyst Density tool, with a cell size of $50 \mathrm{~km}$ and a search radius of $200 \mathrm{~km}$ (Croxall et al. 2005, Phillips et al. 2006). Kernel density contours were overlaid on maps of bathymetry at $1 / 12^{\circ}$ resolution (available from www.gfdl.noaa.gov/products/vis/data/ datasets/TerrainBase.html), and monthly composites of remote-sensed sea surface characteristics: sea surface temperature (SST) in ${ }^{\circ} \mathrm{C}$ and chlorophyll a (chl a) concentrations in $\mathrm{mg} \mathrm{m}^{-3}$. In 2002, the SST data were NOAA Advanced Very-High-Resolution Radiometer (AVHRR) products at $4 \mathrm{~km}$ resolution, downloaded from http://podaac.jpl.nasa.gov, and the chl a data were SeaWIFS products at $9 \mathrm{~km}$ resolution, downloaded from http://oceancolor.gsfc.nasa.gov/. In 2004, both datasets were Aqua MODIS mapped products at $9 \mathrm{~km}$ cell resolution, downloaded from http://oceancolor. gsfc.nasa.gov. Quantitative comparison with skua distribution was restricted to 2 representative months in early winter (May) and late winter (September) in the relevant years.

The loggers tested for saltwater immersion every $3 \mathrm{~s}$ and integrated this into a value between 0 (entirely dry) and 200 (entirely wet) at the end of every $10 \mathrm{~min}$. This was matched with the timing of civil twilight (when the sun is $6^{\circ}$ below the horizon) in order to calculate the proportion of daylight and darkness, and total time spent in flight or on the water, and the proportion of all time spent in flight or on the water each day that took place during darkness. Immersion data were unavailable for part or all of the deployment period for 2 of the Falkland skuas, probably because of goose barnacle growth between the sensor pins (see 'Results').

Stable isotope analysis. Feather samples were dried, stored in sealed plastic bags and later ground to a fine powder in a freezer mill operating at liquid nitrogen temperature prior to stable isotope analysis (SIA). Carbon and nitrogen isotope ratios were measured according to established methods (Bearhop et al. 2006, Cherel et al. 2006) by continuous-flow isotope ratio mass spectrometry, with 3 internal laboratory standards analysed for every 10 unknown samples assuring good matching of results and allowing any instrument drift to be corrected. Stable isotope ratios were expressed in $\delta$ notation as parts per thousand (\%o) deviation from the international standards V-Pee Dee belemnite (carbon) and AIR (nitrogen). Measurement precision of both $\delta^{15} \mathrm{~N}$ and $\delta^{13} \mathrm{C}$ was estimated to be $\leq 0.2 \%$. Moult in skuas takes place predominantly away from breeding colonies (Furness 1987), and none of the several hundred skuas caught at Bird Island in November to February 2000/01 to 2002/03 were in active body moult (British Antarctic Survey [BAS] 
unpubl. data). Therefore, isotope values in these feathers represent diet during the non-breeding period. Values for skuas were compared to those in body feathers collected from adult black-browed albatrosses and white-chinned petrels Procellaria aequinoctialis in the same season (2001/02; BAS unpubl. data). All values are presented as means $\pm 1 \mathrm{SD}$.

\section{RESULTS}

\section{Retrieval details and device effects}

Eight (29\%) of the 28 breeding birds fitted with loggers at Bird Island in 2001/02 bred in the following season, 7 of which were recaptured and the logger retrieved. One of these 7 loggers failed to download, and 3 of the 6 that did download were of the design that timed-out after $300 \mathrm{~d}$ and did not collect immersion data. At New Island, 2 of the 30 loggers deployed on breeding birds were lost soon after deployment (both birds survived until the following season). Six ( $21 \%$ ) of the remaining 28 birds were seen the following year, 4 of which were recaptured (3 of which were breeding); 1 bird was seen only once and another lost its logger shortly after arrival. Only 1 bird at Bird Island (possibly the individual that was not recaptured in 2002/03) and no further birds at New Island were seen with loggers in subsequent years (to 2006/07). All birds that returned to New Island had goose barnacles Lepas spp. attached to their loggers, but these were lost within 2 to $3 \mathrm{~d}$ ashore.

Breeding success of instrumented skuas was similar to that of controls at Bird Island in the season of deployment $\left(0.75\right.$ chicks pair ${ }^{-1}, \mathrm{n}=16$; cf. 0.69 chicks pair ${ }^{-1}$ in controls, $\mathrm{n}=26$ ) and of retrieval (1.13 chicks pair $^{-1}, \mathrm{n}=8$; cf. 0.94 chicks pair ${ }^{-1}$ in controls, $\mathrm{n}=34$ ), and at New Island in the season of deployment (0.07 chicks pair ${ }^{-1}, \mathrm{n}=30$; cf. 0.05 chicks pair ${ }^{-1}$ in controls, $\mathrm{n}=42$ pairs). At Bird Island, mean adult mass and hatching date of the birds that returned with loggers were similar to those of controls (incubation mass $1909 \pm 223 \mathrm{~g}, \mathrm{n}=7$; cf. $1893 \pm 146 \mathrm{~g}$, in controls, $\mathrm{n}=16$, $t$-test, $t_{21}=0.21, \mathrm{p}=0.84$; hatching date 6 January \pm $4.6 \mathrm{~d}, \mathrm{n}=7$; cf. 4 January $\pm 7.1 \mathrm{~d}$ in controls, $\mathrm{n}=28$, $t$-test, $\left.t_{33}=0.64, \mathrm{p}=0.53\right)$.

\section{Wintering distribution from loggers}

Of the respective 1762 and 1456 locations obtained outside the equinox period from brown skuas $(\mathrm{n}=6)$ and from Falkland skuas $(\mathrm{n}=4), 7.8$ and $14.1 \%$ were later excluded because of light level interference, and 1.8 and $0.9 \%$ because of unrealistic flight speeds, resulting in 1556 and 1238 validated locations for the 2 species, respectively. Brown skuas that bred successfully departed 1 to $3 \mathrm{wk}$ after their chick(s) fledged, on 2 to 26 March (mean: 11 March, $n=3$ ). Birds that failed departed much earlier (mean: 20 February, range: 15 to 26 February, $n=3$ ). In contrast, Falkland skuas, all of which failed in January, did not depart until 2 to 3 mo later (mean: 22 March, range: 10 March to 7 April, $\mathrm{n}=4$ ). All tracked birds returned much earlier to land at South Georgia (mean: 6 October, range: 30 September to 15 October, $\mathrm{n}=3$ ), than at the Falklands (mean: 15 November, range: 31 October to 24 November, $\mathrm{n}=$ 4), which concurs with typical return dates of untagged birds at these sites (authors' unpubl. data).

During winter, the brown skuas were distributed widely within the Argentine Basin (37 to $52^{\circ} \mathrm{S}$ ) between the Antarctic Polar Front (APF) and the northern extent of the sub-tropical Front mainly in deep, subantarctic waters, and towards their northern margin also in mixed subantarctic-subtropical waters (Fig. 1). In contrast, although the Falkland skuas wintered at similar latitudes $\left(40\right.$ to $\left.52^{\circ} \mathrm{S}\right)$, they were concentrated mainly in subantarctic waters around the central Patagonian shelf-break, extending to the west onto the open shelf and to the east into the south-west portion of the Argentine Basin, overlapping only partially with the brown skuas (Figs. $1 \& 2$ ). At the overall species level, there was no overlap in core areas $(40 \%$ kernels), but increasing overlap in lower density kernels. There was much greater overlap among core areas of individual birds within than between species, with no obvious influence of sex on distribution (Fig. 2).

Oceanographic characteristics of the wintering areas are indicated in Table 1. Both species wintered in regions of very deep water, typically ca. 4750 to $5300 \mathrm{~m}$ for brown skuas and 2750 to $4100 \mathrm{~m}$ for Falkland skuas (Table 1). SST regimes were similar for both species in May (means of 8 to $10^{\circ} \mathrm{C}$ ). Water temperatures were at similar levels in September in the highest density areas (60\% kernels) used by brown skuas, but by that time those occupied by Falkland skuas were much colder (5.5 to $6.9^{\circ} \mathrm{C}$ ). Productivity ( $\mathrm{chl}$ a) was relatively low (generally 0.26 to $0.47 \mathrm{mg} \mathrm{m}^{-3}$ ) within the distributions of both species and varied little between May and September.

\section{Pre-laying exodus}

Several weeks after their first return to South Georgia, on 8 November and 30 October, respectively, 1 male and one of the 2 female brown skuas returned to sea on a pre-laying trip that lasted 8 and $9 \mathrm{~d}$, respectively. These were to subantarctic and mixed subantarctic-subtropical waters around 500 to $1000 \mathrm{~km}$ north of South Georgia. 

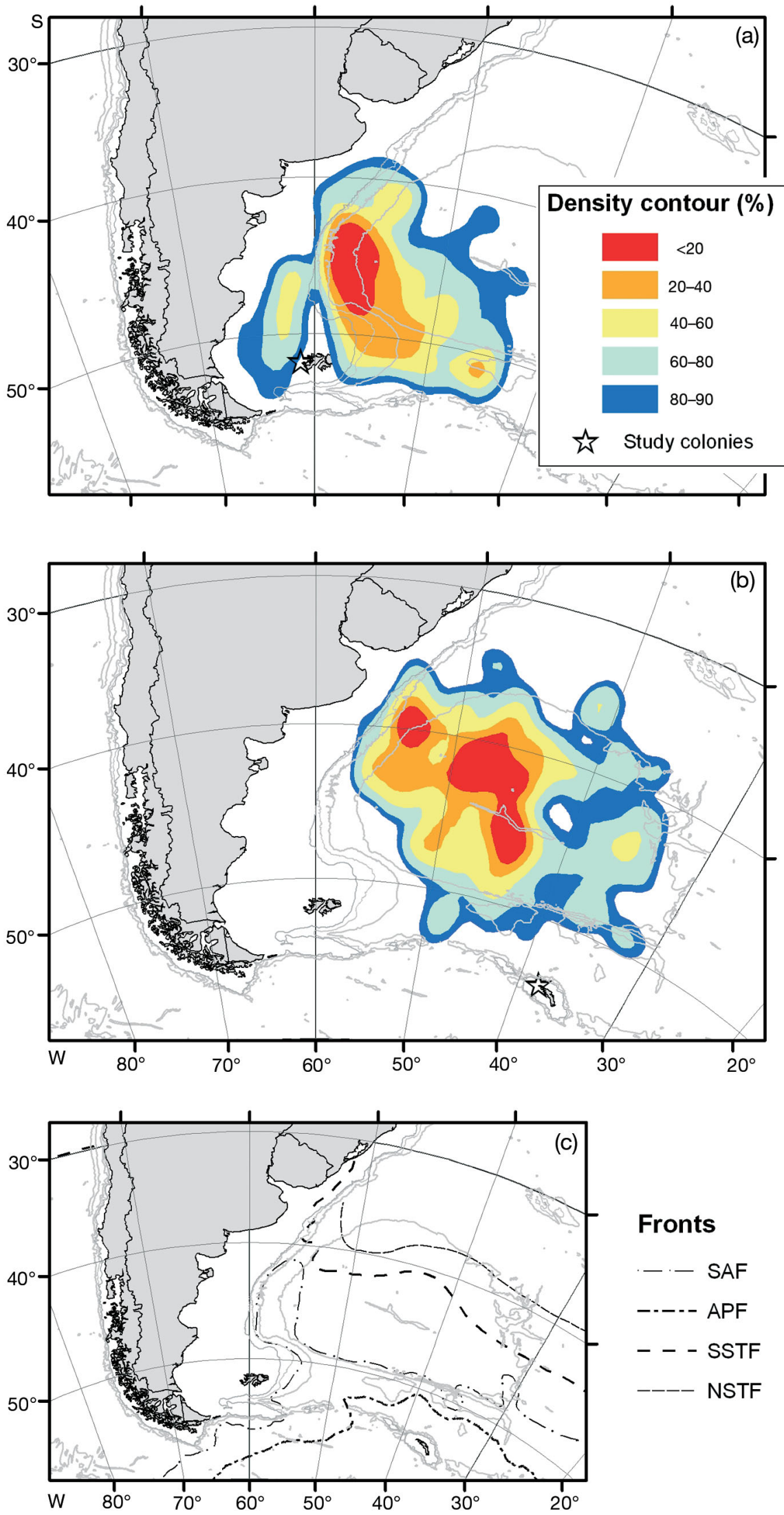

Fronts - - SAF

--- - APF

- - - SSTF

NSTF

\section{Activity patterns}

Both species of skua spent a very high proportion of darkness (83.9 to $93.3 \%$; on average 10.4 to $12.0 \mathrm{~h}$ night $^{-1}$ ), and to a lesser extent daylight ( 73.9 to $92.1 \%$; on average 8.5 to $10.2 \mathrm{~h} \mathrm{day}^{-1}$ ) on the water during the winter (Table 2), a pattern that was established from the first or second day that the bird left the colony. Note that as the 2 species wintered at similar latitudes, day lengths experienced were very similar (on average $12.5 \mathrm{~h}$ of darkness and $11.5 \mathrm{~h}$ of daylight). Although in most cases marginally non-significant because of the small sample size (means from 3 birds at each site), Falkland skuas tended to spend a greater proportion of time on the water, more time in total on the water and less time in flight during daylight, darkness and overall, respectively, compared to brown skuas ( $t$-tests, $t_{4}=$ 2.2 to $3.4, p=0.03$ to 0.09 ). Falkland skuas also tended to undertake a higher proportion of daily flight during darkness $\left(t_{4}=2.5, \mathrm{p}=0.06\right)$, but there was little difference in the proportion of daily time spent on the water that occurred during darkness $\left(t_{4}=0.06, \mathrm{p}=0.95\right)$. During pre-laying trips, the 2 brown skuas spent a slightly greater proportion of both daylight (82.4 vs. $77.9 \%)$ and darkness (95.1 vs. $86.1 \%$ ) on the water compared to during the winter (Table 2). The proportion of daily time on the

Fig. 1. Catharacta lonnbergi and C. antarctica. Density distribution of (a) nonbreeding Falkland skuas from New Island in winter 2004 ( $\mathrm{n}=4$ birds), (b) nonbreeding brown skuas from South Georgia in winter 2002 ( $\mathrm{n}=6$ birds) and (c) regional oceanography showing approximate location of the Antarctic Polar Front (APF), Subantarctic Front (SAF), North Subtropical Front (NSTF) and South Subtropical Front (SSTF), based on Belkin \& Gordon (1996). Bathymetric contours are 500, 1000, 2000 and $5000 \mathrm{~m}$ 

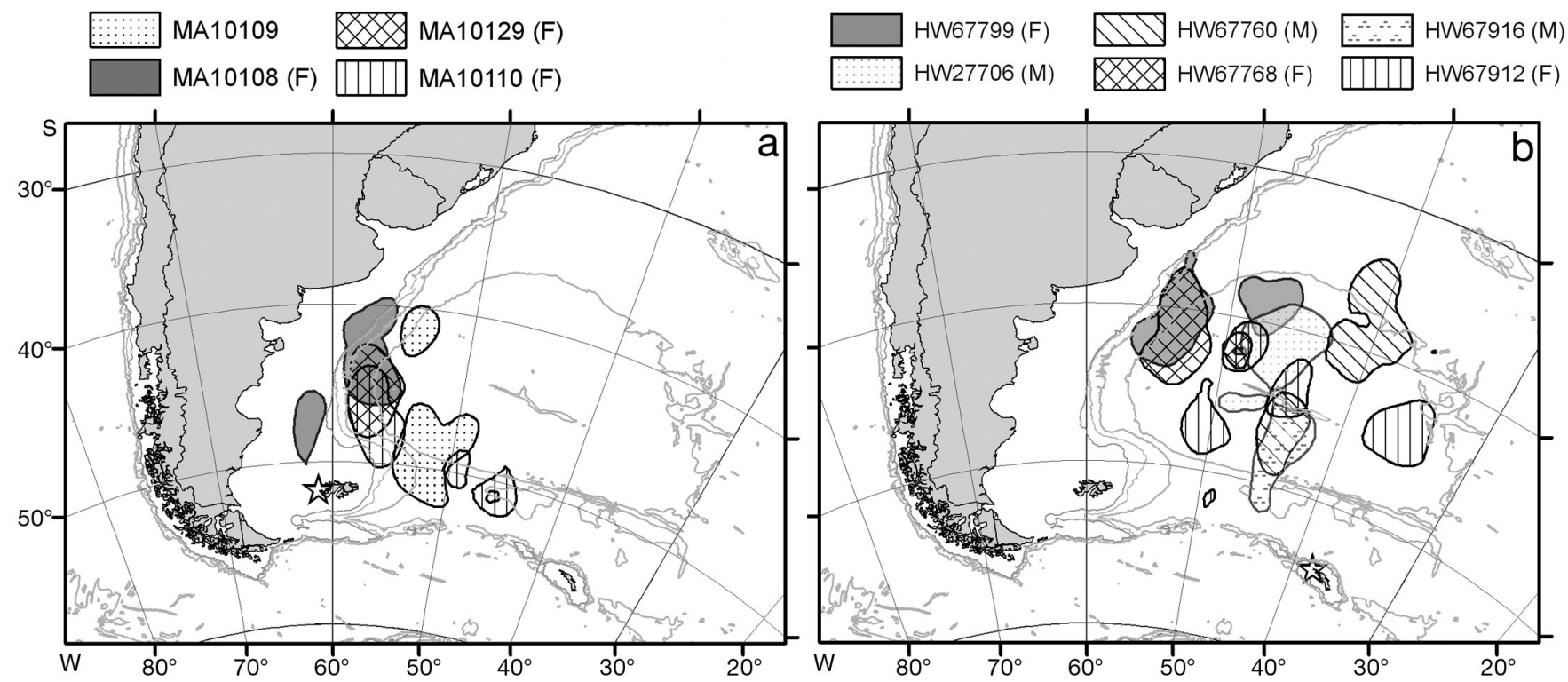

Fig. 2. Catharacta lonnbergi and C. antarctica. Core areas (40\% kernel contours) of individual (a) Falkland skuas (n $=4)$ in winter 2004 and (b) brown skuas $(\mathrm{n}=6)$ in winter 2002. (F): female; $(\mathrm{M})$ : male; one of the Falkland skuas was of unknown sex; bathymetric contours are 500, 1000, 2000 and $5000 \mathrm{~m}$; 咨: study colonies

water that occurred during darkness on the pre-laying trip was lower (39.7 vs. $53.8 \%$ ), and the proportion of flight that occurred at night was much lower (1.8 vs. $31.3 \%$ ) than during the winter.

\section{Stable isotope results}

Mean feather $\delta^{15} \mathrm{~N}$ and $\delta^{13} \mathrm{C}$ values of brown skuas from Bird Island were $10.4 \pm 0.7$ and $-17.8 \pm 0.6 \%$ o $(\mathrm{n}=$
40), respectively, and although there was 1 outlier (Fig. 3), showed low overall variance (coefficients of variation of 7.1 and $3.1 \%$, respectively). Although females tended to have higher $\delta^{15} \mathrm{~N}$ values, differences in isotope values between sexes were non-significant ( $t$-tests, $t_{38}=1.87, \mathrm{p}=0.07$ for $\delta^{15} \mathrm{~N}$, and $t_{38}=0.81, \mathrm{p}=$ 0.43 for $\delta^{13} \mathrm{C}$ ). There was no significant difference in mean $\delta^{15} \mathrm{~N}$ or $\delta^{13} \mathrm{C}$ values between the 7 brown skuas from which loggers were retrieved and the 33 other individuals sampled in 2000/01 (Fig. 3 ; $t$-tests, $t_{38}=0.50$,

Table 1. Catharacta lonnbergi and C. antarctica. Bathymetric and oceanographic characteristics within the kernel density distributions of wintering skuas in 2002 and 2004, respectively. Values are means \pm SD (range). SST: sea surface temperature

\begin{tabular}{|c|c|c|c|c|c|}
\hline \multirow[t]{2}{*}{ Kernel (\%) } & \multirow{2}{*}{$\begin{array}{l}\text { Water depth } \\
\qquad(\mathrm{m})\end{array}$} & \multicolumn{2}{|c|}{$\operatorname{SST}\left({ }^{\circ} \mathrm{C}\right)$} & \multicolumn{2}{|c|}{ Chl a conc. $\left(\mathrm{mg} \mathrm{m}^{-3}\right)$} \\
\hline & & May & Sep & May & Sep \\
\hline \multicolumn{6}{|l|}{ Brown skua } \\
\hline 0 to 20 & $\begin{array}{c}5144 \pm 399 \\
(1807-5934)\end{array}$ & $\begin{array}{c}9.9 \pm 5.4 \\
(-2.9-21.8)\end{array}$ & $\begin{array}{c}10.6 \pm 3.0 \\
(-2.9-17.1)\end{array}$ & $\begin{array}{l}0.31 \pm 0.10 \\
(0.12-2.79)\end{array}$ & $\begin{array}{l}0.40 \pm 0.26 \\
(0.15-5.75)\end{array}$ \\
\hline 20 to 40 & $\begin{array}{c}5271 \pm 636 \\
(1095-6043)\end{array}$ & $\begin{array}{c}10.4 \pm 5.5 \\
(-2.9-22.4)\end{array}$ & $\begin{array}{c}10.4 \pm 3.1 \\
(-2.9-16.3)\end{array}$ & $\begin{array}{c}0.34 \pm 0.24 \\
(0.12-6.61)\end{array}$ & $\begin{array}{l}0.47 \pm 0.31 \\
(0.12-7.08)\end{array}$ \\
\hline 40 to 60 & $\begin{array}{l}5262 \pm 998 \\
(648-6196)\end{array}$ & $\begin{array}{c}9.7 \pm 6.2 \\
(-2.9-23.0)\end{array}$ & $\begin{array}{c}9.2 \pm 4.0 \\
(-2.9-17.6)\end{array}$ & $\begin{array}{c}0.32 \pm 0.32 \\
(0.09-19.95)\end{array}$ & $\begin{array}{l}0.38 \pm 0.21 \\
(0.06-5.01)\end{array}$ \\
\hline 60 to 80 & $\begin{array}{c}4753 \pm 1316 \\
(16-6349)\end{array}$ & $\begin{array}{c}10.1 \pm 5.6 \\
(-2.9-23.0)\end{array}$ & $\begin{array}{c}7.9 \pm 5.3 \\
(-2.9-19.3)\end{array}$ & $\begin{array}{l}0.26 \pm 0.19 \\
(0.06-4.84)\end{array}$ & $\begin{array}{l}0.31 \pm 0.29 \\
(0.08-7.33)\end{array}$ \\
\hline \multicolumn{6}{|c|}{ Falkland skua } \\
\hline 0 to 20 & $\begin{array}{l}4092 \pm 1185 \\
(1186-5661)\end{array}$ & $\begin{array}{l}10.2 \pm 1.8 \\
(6.3-13.2)\end{array}$ & $\begin{array}{l}6.4 \pm 1.0 \\
(4.2-9.6)\end{array}$ & $\begin{array}{l}0.38 \pm 0.18 \\
(0.15-4.22)\end{array}$ & $\begin{array}{l}0.44 \pm 0.29 \\
(0.15-2.51)\end{array}$ \\
\hline 20 to 40 & $\begin{array}{c}3116 \pm 2004 \\
(373-6171)\end{array}$ & $\begin{array}{c}8.0 \pm 2.4 \\
(3.0-15.0)\end{array}$ & $\begin{array}{c}5.5 \pm 1.9 \\
(1.9-10.9)\end{array}$ & $\begin{array}{l}0.28 \pm 0.21 \\
(0.05-6.38)\end{array}$ & $\begin{array}{l}0.26 \pm 0.24 \\
(0.13-2.79)\end{array}$ \\
\hline 40 to 60 & $\begin{array}{c}3375 \pm 2213 \\
(1-6349)\end{array}$ & $\begin{array}{c}9.1 \pm 3.1 \\
(0.9-16.6)\end{array}$ & $\begin{array}{c}6.4 \pm 2.7 \\
(1.9-15.3)\end{array}$ & $\begin{array}{c}0.40 \pm 0.50 \\
(0.06-21.38)\end{array}$ & $\begin{array}{l}0.40 \pm 0.38 \\
(0.11-5.01)\end{array}$ \\
\hline 60 to 80 & $\begin{array}{c}2740 \pm 2459 \\
(90-6261)\end{array}$ & $\begin{array}{c}9.6 \pm 2.7 \\
(0.1-19.5)\end{array}$ & $\begin{array}{c}6.9 \pm 2.9 \\
(1.0-16.2)\end{array}$ & $\begin{array}{c}0.47 \pm 0.42 \\
(0.04-11.89)\end{array}$ & $\begin{array}{c}0.65 \pm 1.37 \\
(0.09-19.28)\end{array}$ \\
\hline
\end{tabular}




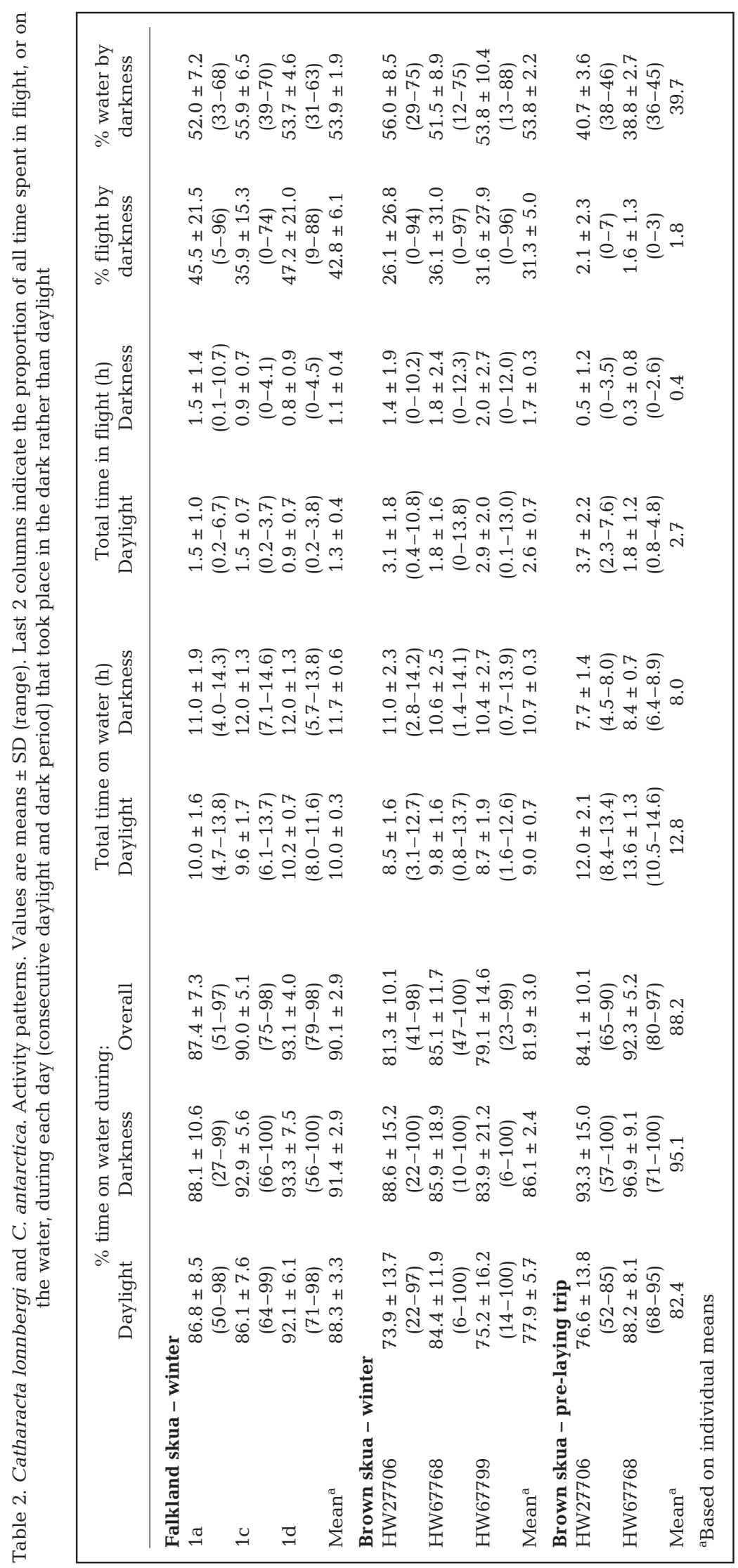

$\mathrm{p}=0.62$ for $\delta^{15} \mathrm{~N}$, and $t_{38}=0.13, \mathrm{p}=0.90$ for $\delta^{13} \mathrm{C}$ ), suggesting that all birds in the sampled population probably fed at broadly similar trophic levels and in isotopically similar water masses. There were also high correlations in isotope values of the 7 birds sampled in consecutive years; however, this was only marginally significant for $\delta^{13} \mathrm{C}$, probably because of the small sample (correlation, $r_{5}=0.96, \mathrm{p}=0.001$ for $\delta^{15} \mathrm{~N}$, and $r_{5}=0.69$, $\mathrm{p}=0.09$ for $\delta^{13} \mathrm{C}$ ). This implies that individuals maintained the same trophic position and general foraging area in the 2 winters. All brown skua isotope signatures were very different from those of white-chinned petrels and blackbrowed albatrosses sampled in the same season (Fig. 3).

\section{DISCUSSION}

This is the first published study of the wintering ranges and activity patterns of skuas from any colony. Although the sample sizes were relatively small (4 to 6 individuals from each site), the similarity in feather isotope signatures of the tracked birds and a much larger sample of brown skuas $(\mathrm{n}=33)$ indicate that all of these birds almost certainly used the same water masses in the nonbreeding period. Comprehensive at-sea surveys over several years in Falkland Islands waters concluded that the only Falkland skuas to remain in the area during the winter months were far to the north (White et al. 2001), in agreement with our results. Hence there is no reason to believe that the wintering ranges of the tracked birds in this study were unrepresentative of the breeding populations as a whole. The high correlations ( $\mathrm{r}>$ $0.7)$ in both $\delta^{13} \mathrm{C}$ and $\delta^{15} \mathrm{~N}$ in feathers of brown skuas sampled in consecutive years (for similar results in great skuas, see Bearhop et al. 2000) indicate that individuals probably migrate to the same areas and maintain similar diet preferences from one winter to the next. Similar large-scale regional site-fidelity has been recorded in other species tracked using GLS loggers in consecutive years, and may well be a universal 


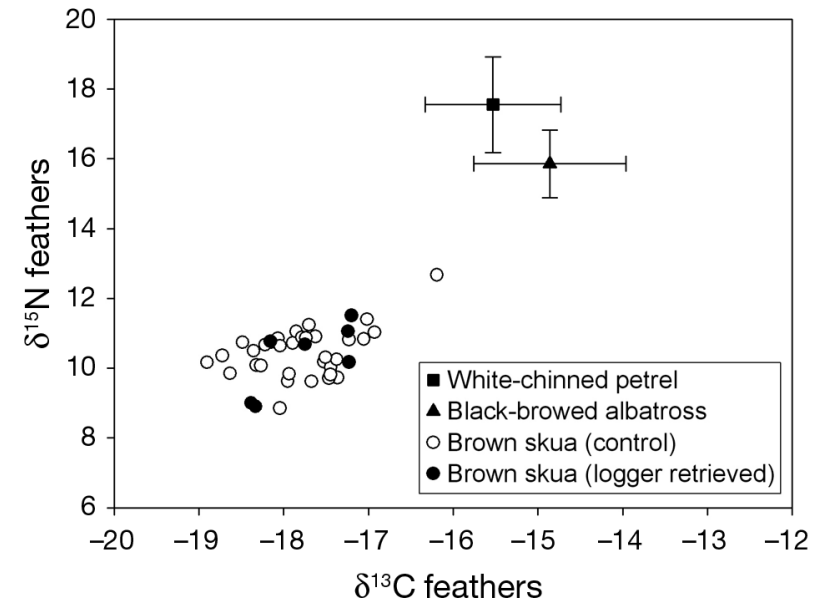

Fig. 3. Stable isotope signatures of brown skua, white-chinned petrel and black-browed albatross body feathers sampled at Bird Island in 2001/02. Individual values are shown for skuas and means \pm SD error bars for the other species

feature of seabirds (Croxall et al. 2005, Phillips et al. 2005b, 2006).

The loggers nonetheless appeared to have deleterious effects on some birds. Although the brown skuas that returned with devices had body condition, hatching dates and breeding success similar to controls at Bird Island, return rates of 21 to $29 \%$ at the 2 sites were considerably less than expected given the high annual survival and low nonbreeding rates of Catharacta skuas in general (Catry et al. 1998, Ratcliffe et al. 2002). The low return rate of instrumented birds at South Georgia was initially attributed to poor winter or early summer feeding conditions, as skuas breeding elsewhere in the South Atlantic (Falklands and Antarctic peninsula region) in 2002/03 also returned in low numbers, few laid and most failed (BAS unpubl. data). Moreover, the additional mass of the logger was equivalent to only $\sim 0.5 \%$ of body mass, which is far less than that expected to cause problems in such large birds (Phillips et al. 2003). However, the observations in the Falklands suggest that goose barnacle accretion may have been a dominant factor. Many stalked barnacles, including Lepas spp., grow rapidly (Green et al. 1994), and following settlement this would have led to a gradual increase in load on the leg, impaired flight performance and manoeuvrability, and potentially increased mortality. As the barnacles appeared to attach to the self-amalgamating tape wrapped round the logger, we have since discontinued this practice and recommend that it be avoided by other researchers. Skuas spend a much greater proportion of time on the water than albatrosses and petrels tracked using similar methods, which probably explains why this problem was not encountered previously.
There was a high degree of spatial segregation in core ranges (40\% kernels) of brown and Falkland skuas, although more overlap in increasingly peripheral portions of their distributions (Fig. 1). Brown skuas wintered mainly within the Argentine Basin $\left(37\right.$ to $52^{\circ} \mathrm{S}$ ) in subantarctic and mixed subantarcticsubtropical water from north of the APF to the northern extent of the sub-tropical convergence. Two of 3 birds returned to the eastern part of this range during a prelaying exodus, which to our knowledge is the first time this behaviour has been described for any skua. Activity patterns on these trips were similar to those during the winter, although less of the total daily flight took place in darkness. The western part of the wintering range in particular has high eddy variability because of the large-scale meanders of the Brazil Current and the offshore edge of the Falklands Current, and the region was characterised by fairly stable water temperatures (means of 7.9 to $10.6^{\circ} \mathrm{C}$; Table 1 ).

In contrast, Falkland skuas occupied waters to the south and west predominantly in the transition region between subpolar and shelf waters on the Patagonian shelf-break, and to a lesser extent on the open shelf. Here water temperatures dropped considerably from early to late winter (from means of $8.0-10.2^{\circ} \mathrm{C}$ to $5.5-6.9^{\circ} \mathrm{C}$ ), which is a fairly consistent pattern for the region. The shelf-break is a highly productive area during the summer but less so in the winter, when mean chl $a$ values differed little from those in deep waters in the Argentine Basin utilised by the brown skuas (Table 1). Although the comparison of SST and chl a does not indicate particularly divergent habitat preferences in early winter, the region used by Falkland skuas is colder in late winter, and the 2 species clearly differ in typical water depth used, with areas used by Falkland skuas $\sim 2750$ to $4100 \mathrm{~m}$ deep and areas used by brown skuas $\sim 450$ to $5300 \mathrm{~m}$ deep. This contrasts with the much more coastal preferences, e.g., of great skuas Catharacta skua in the North Atlantic (Furness 1987).

The partial spatial segregation and variation in habitat preferences (mainly in terms of water depth) of the 2 species indicate a degree of niche specialisation that was also reflected in divergence in winter activity patterns. Compared to Falkland skuas, brown skuas spent a significantly greater proportion of both daylight and darkness, and more hours on average, in flight, indicative of greater search effort. In addition, more of their daily flight activity took place during the day. It is difficult to surmise which factor(s) might underlie the differences in environmental preferences and behaviour, but it could be related to body size. Brown skuas are 10 to $17 \%$ larger in linear dimensions than Falkland skuas, and there is no overlap within-sex in either tarsus or wing length (Votier et al. 2004). This suggests that smaller body size (and hence greater manoeuvra- 
bility) might be favoured in the wintering areas of Falkland compared to brown skuas. It is difficult to separate cause and effect, however, and in order to rule out an alternative hypothesis, i.e. that the segregation results from dominance and competitive exclusion, further research is required.

It is noteworthy that the wintering areas of both species are not particularly productive, at least in comparison to those on the Patagonian Shelf exploited by white-chinned petrels at the same time of year (Phillips et al. 2006). The distributions overlap little with nonbreeding white-chinned petrel and black-browed albatross from South Georgia, to a slightly greater extent with nonbreeding grey-headed albatross Thalassarche chrysostoma from South Georgia and blackbrowed albatross from the Falklands, and most with winter-breeding wandering albatross Diomedea exulans (Grémillet et al. 2000, Croxall et al. 2005, Phillips et al. 2005b, 2006). This last species flies in long, looping arcs, covering vast distances in search of presumably sparsely distributed prey, predominantly the large squid Kondakovia longimana (Xavier et al. 2004), and there is no overlap in isotope values (BAS unpubl. data). However, the activity patterns of both brown and Falkland skuas are very different from those of wandering or other albatrosses during the breeding season, which are all much more aerial, spending a much lower proportion of time on the water, particularly during daylight (Grémillet et al. 2000, Xavier et al. 2004, Phalan et al. 2007). Similarly, although blackbrowed albatrosses from the Falklands make fewer landings, remain on the surface for longer each time and spend a greater proportion of their day (63 vs. $48 \%$ ) on the water during the nonbreeding compared to the breeding period (Grémillet et al. 2000), they nonetheless showed considerably more flight activity than the wintering skuas in our study. This implies little direct competition for the same resources. Incidentally, it is important to note that the skua activity patterns were established from the first or second day after the birds had departed the colony and could not therefore be an artefact of goose barnacle accretion, which would have taken a minimum of several weeks to become a nuisance.

There are very few data on the winter diet of skuas (Furness 1987). Conventional sampling indicates that during the breeding season, brown skuas at South Georgia feed initially mainly on carrion and then switch to seabird predation during chick-rearing (Phillips et al. 2004a). Anecdotal observations for Falkland skuas similarly suggest that they feed to a considerable extent on other seabirds. This is in broad agreement with logger data indicating that adult brown skuas spend little or no time at sea during summer even after nest failure, but failed Falkland skuas spend a proportion of daylight (8 to $27 \%$ ) and occasional nights on the water before final departure from the colony (authors' unpubl. data), and therefore may incorporate more marine prey into their diet than previously suspected. This is not likely to be offal or discards, as skuas are rarely observed behind fishing vessels either in Falkland waters or close to the Argentine coast (Yorio \& Caille 1999, White et al. 2001).

Isotope values provide clues as to the winter diet of the brown skua, although this is hampered by the paucity of data on prey isotope signatures in the appropriate area. Nitrogen isotope values provide an indicator of trophic status, and those of the skua feathers $(10.4 \%$ o) were similar to those in the flesh of planktivorous/partially piscivorous fish and squid sampled at more southerly latitudes in the Indian Ocean (8.1 to $10.2 \%$ and 8.0 to $11.9 \%$, respectively: Cherel et al. 2000). As they have comparable feather $\delta^{13} \mathrm{C}$ values, Antarctic prions Pachyptila desolata from South Georgia probably winter at similar latitudes to the skuas (Cherel et al. 2006). Around the breeding colony, prions and other small petrels feed primarily on euphausiids and copepods (Reid et al. 1997) and may well maintain similar dietary preferences throughout the year. As the feather $\delta^{15} \mathrm{~N}$ signatures of wintering brown skuas are only $1 \%$ greater than those of prions (mean 9.5\%o), i.e. less than the expected increase of 3 to $5 \%$ at each trophic level (Michener \& Schell 1994), prions must not be the principal prey. Finally, the similarity between the $\delta^{15} \mathrm{~N}$ signatures of skuas and tuna (Das et al. 2006), which are targeted by pelagic fisheries in the region, suggests little or no reliance on offal. Together, this points toward a mixed diet for the wintering brown skuas of zooplankton, relatively low trophic-level squid and/or fish that they catch for themselves, and potentially few seabirds. They might also feed to an extent by stealing lower trophic-level bait from long-lines or by kleptoparasitism (Spear et al. 1999, White et al. 2001).

As the isotope signatures of the tracked brown skuas were within the range of the larger sample from South Georgia, and there were no apparent differences between the sexes in distribution or $\delta^{13} \mathrm{C}$ values, the great majority of this breeding population almost certainly winter in the south-west Atlantic. None of the birds from South Georgia had isotope signatures characteristic of 2 procellariids (black-browed albatross and white-chinned petrel) that migrate to adjacent continental shelves (this study), nor of skuas breeding on the Patagonian coast (Forero et al. 2004). This concurs with the generally low abundance of Catharacta (presumably Falkland skuas) on the Patagonian Shelf during the winter. Similarly, the Catharacta seen in large numbers off south-west Africa must originate predominantly from breeding populations at Crozet or 
Marion Island in the south-west Indian Ocean, as suggested by ringing recoveries (Weimerskirch et al. 1985, Ryan et al. 2002).

Southern hemisphere skuas other than the south polar skua have been suspected but not yet confirmed in North Atlantic waters. The feather isotope signatures of the brown skuas in this study were not characteristic of adult great skuas breeding in the UK (mean $\delta^{13} \mathrm{C}$ of $-14 \%$ and $\delta^{15} \mathrm{~N}$ of $\sim 14$ to $15 \%$ : Bearhop et al. 2000) that winter mainly off southern European and North African coasts (Furness 1987). Therefore, none of the 40 brown skuas that we sampled appeared to migrate to these regions, and, assuming the tracking data are representative, nor do Falkland skuas. However, a particular migration strategy can be very uncommon; for example, just $3 \%$ of black-browed albatrosses winter on the Patagonian Shelf or in Australian waters (Phillips et al. 2005b). In addition, the only ringing recovery during winter to date of a brown skua from South Georgia was of a 1-yr-old caught at sea off Cape Province, South Africa, in 1985 (BAS unpubl. data). This illustrates that young birds often disperse much more widely than adults, and it therefore cannot be excluded that a proportion of juveniles (and possibly adults) of either species might penetrate the North Atlantic.

Acknowledgements. We are very grateful to Ben Phalan for help with fieldwork on Bird Island, Miguel Lecoq and Rafael Matias for retrieving the loggers on New Island, Debs Dawson and Douglas Ross for sexing birds, Andrew Fleming for access and provision of the remote-sensed datasets, Andreas Cziferszky for assisting with GIS, and Phil Trathan for providing loggers for skuas at Bird Island. Comments from 3 anonymous referees improved the manuscript. Part of this study was supported by Fundação para a Ciência e a Tecnologia (FCT Portugal) through the Programa plurianual (UI\&D 331/94), and P.C. benefited from a postdoctoral fellowship from FCT (Praxis XXI BPD/11631/02). This work was also supported by a NERC Life Sciences Stable Isotope Facility Grant (SUERC Proposal Number 50-5/02).

\section{LITERATURE CITED}

Bearhop S, Phillips RA, Thompson DR, Waldron S, Furness RW (2000) Variability in mercury concentrations of great skuas Catharacta skua: the influence of colony, diet and trophic status inferred from stable isotope signatures. Mar Ecol Prog Ser 195:261-268

Bearhop S, Phillips RA, McGill R, Cherel Y, Dawson DA, Croxall JP (2006) Stable isotopes indicate sex-specific and long-term individual foraging specialisation in diving seabirds. Mar Ecol Prog Ser 311:157-164

Belkin IM, Gordon AL (1996) Southern Ocean fronts from the Greenwich meridian to Tasmania. J Geophys Res 101: 3675-3696

Brothers N, Gales R, Hedd A, Robertson G (1998) Foraging movements of the shy albatross Diomedea cauta breeding in Australia; implications for interactions with longline fisheries. Ibis 140:446-457
Catry P, Phillips RA, Hamer KC, Ratcliffe N, Furness RW (1998) The incidence of nonbreeding by adult great skuas and parasitic jaegers from Foula, Shetland. Condor 100: $448-455$

Cherel Y, Hobson KA, Weimerskirch H (2000) Using stableisotope analysis of feathers to distinguish moulting and breeding origins of seabirds. Oecologia 122:155-162

Cherel Y, Phillips RA, Hobson KA, McGill R (2006) Stable isotope evidence of diverse species-specific and individual wintering strategies in seabirds. Biol Lett 2:301-303

Croxall JP, Silk JRD, Phillips RA, Afanasyev V, Briggs DR (2005) Global circumnavigations: tracking year-round ranges of non-breeding albatrosses. Science 307:249-250

Das K, Lepoint G, Loizeau V, Debacker V, Dauby P, Bouqueqneau JM (2006) Tuna and dolphin associations in the North-east Atlantic: evidence of different ecological niches from stable isotope and heavy metal measurements. Mar Pollut Bull 40:102-109

Fairbairn J, Shine R (1993) Patterns of sexual size dimorphism in seabirds of the Southern Hemisphere. Oikos 68:139-145

Forero MG, Bortolotti GR, Hobson KA, Donazar JA, Bertelloti M, Blanco G (2004) High trophic overlap within the seabird community of Argentinean Patagonia: a multiscale approach. J Anim Ecol 73:789-801

Furness RW (1987) The Skuas. T. \& A.D. Poyser, Calton, Staffordshire

Green A, Tyler PA, Angel MV, Gage JD (1994) Gametogenesis in deep- and surface-dwelling oceanic stalked barnacles from the NE Atlantic Ocean. J Exp Mar Biol Ecol 184:143-158

Grémillet D, Wilson RP, Wanless S, Chater T (2000) Blackbrowed albatross, international fisheries and the Patagonian Shelf. Mar Ecol Prog Ser 195:269-280

Huin N (2002) Foraging distribution of the black-browed albatross, Thalassarche melanophris, breeding in the Falkland Islands. Aquat Conserv: Mar Freshw Ecosyst 12: 89-99

Hyrenbach KD, Fernández P, Anderson DJ (2002) Oceanographic habitats of two sympatric North Pacific albatrosses during the breeding season. Mar Ecol Prog Ser 233: 283-301

Marchant S, Higgins PJ (1990) Handbook of Australian, New Zealand and Antarctic birds, Vol 1. Oxford University Press, Melbourne

Michener RH, Schell DM (1994) Stable isotope ratios as tracers in marine aquatic food webs. In: Lajtha K, Michener $\mathrm{RH}$ (eds) Stable isotopes in ecology and environmental science. Blackwell Scientific, Oxford, p 138-158

Phalan B, Phillips RA, Silk JRD, Afanasyev V and 5 others (2007) Foraging behaviour of four albatross species by night and day. Mar Ecol Prog Ser 340:271-286

Phillips RA, Catry P, Thompson DR, Hamer KC, Furness RW (1997) Inter-colony variation in diet and reproductive performance of great skuas Catharacta skua. Mar Ecol Prog Ser 152:285-293

Phillips RA, Xavier JC, Croxall JP (2003) Effects of satellite transmitters on albatrosses and petrels. Auk 120: 1082-1090

Phillips RA, Phalan B, Forster IP (2004a) Diet and long-term changes in population size and productivity of brown skuas Catharacta antarctica lonnbergi at Bird Island, South Georgia. Polar Biol 27:555-561

Phillips RA, Silk JRD, Croxall JP, Afanasyev V, Briggs DR (2004b) Accuracy of geolocation estimates for flying seabirds. Mar Ecol Prog Ser 266:265-272

Phillips RA, Silk JRD, Croxall JP (2005a) Foraging and provisioning strategies of the light-mantled sooty albatross at 
South Georgia: competition and co-existence with sympatric pelagic predators. Mar Ecol Prog Ser 285:259-270

Phillips RA, Silk JRD, Croxall JP, Afanasyev V, Bennett VJ (2005b) Summer distribution and migration of nonbreeding albatrosses: individual consistencies and implications for conservation. Ecology 86:2386-2396

Phillips RA, Silk JRD, Croxall JP, Afanasyev V (2006) Yearround distribution of white-chinned petrels from South Georgia: relationships with oceanography and fisheries. Biol Conserv 129:336-347

Ratcliffe N, Catry P, Hamer KC, Klomp NI, Furness RW (2002) The effect of age and year on the survival of breeding adult great skuas Catharacta skua in Shetland. Ibis 144: 384-392

Reid K, Croxall JP, Edwards TM (1997) Interannual variation in the diet of the Antarctic prion Pachyptila desolata at South Georgia. Emu 97:126-132

Ryan PG, Keith DG, Kroese M (2002) Seabird bycatch by tuna longline fisheries off southern Africa, 1998-2000. S Afr J Mar Sci 24:103-110

Serrano-Meneses MA, Székely T (2006) Sexual size dimorphism in seabirds: sexual selection, fecundity selection and differential niche-utilisation. Oikos 113:385-394

Shaffer SA, Tremblay Y, Weimerskirch H, Scott D and 7 others (2006) Migratory shearwaters integrate oceanic resources across the Pacific Ocean in an endless summer. Proc Natl Acad Sci USA 103:12799-12802

Editorial responsibility: Rory Wilson (Contributing Editor), Swansea, UK
Spear LB, Howell SNG, Oedekoven CS, Legay D, Bried J (1999) Kleptoparasitism by brown skuas on albatrosses and giant-petrels in the Indian Ocean. Auk 116:545-548

Votier SC, Bearhop S, Newell RG, Orr K, Furness RW, Kennedy M (2004) The first record of brown skuas Catharacta antarctica in Europe. Ibis 146:95-102

Waugh S, Weimerskirch H (2003) Environmental heterogeneity and the evolution of foraging behaviour in long ranging greater albatrosses. Oikos 103:374-384

Weimerskirch H, Jouventin P, Mougin JL, Stahl JC, van Beveren $M$ (1985) Banding recoveries and the dispersal of seabirds breeding in French Austral and Antarctic territories. Emu 85:22-33

Wernham CV, Toms MP, Marchant JH, Clark JA, Siriwardena GM, Baillie SR (2002) The migration atlas: movements of the birds of Britain and Ireland. T. \& A.D. Poyser, London

White RWG, Gillon KW, Black AD, Reid JB (2001) The distribution of seabirds and marine mammals in Falkland Islands waters. Joint Nature Conservation Committee, Peterborough

Xavier JC, Trathan PN, Croxall JP, Wood AG, Podesta G, Rodhouse PG (2004) Foraging ecology and interactions with fisheries of wandering albatrosses (Diomedea exulans) breeding at South Georgia. Fish Oceanogr 13:324-344

Yorio P, Caille G (1999) Seabird interactions with coastal fisheries in northern Patagonia: use of discards and incidental captures in nets. Waterbirds 22:207-216

Submitted: December 1, 2006; Accepted: March 19, 2007 Proofs received from author(s): August 31, 2007, 2007 